\title{
Physiological Activities of Parsley Extracts as an Ingredient of Functional Cosmetics
}

\author{
Jung-Eun Choi $^{1}$, Ji-Sun Moon ${ }^{2 *}$ \\ ${ }^{1}$ Department of Bioengineering, Konkuk University, Seoul, Korea \\ ${ }^{2}$ Department of Beauty and Health, Jungwon University, Goesan-gun, Chungcheongbuk-do, Korea
}

\author{
"Corresponding author: Ji-Sun Moon, \\ Department of Beauty and Health, Jungwon \\ University, 85 Munmu-ro, Goesan-eup, \\ Goesan-gun, Chungcheongbuk-do 28024 \\ Korea \\ Tel.: +82438308865 \\ Fax: +82438308679 \\ Email: wltjs55555@naver.com \\ Received July 27, 2017 \\ Revised September 18, 2017 \\ Accepted September 28, 2017 \\ Published December 30, 2017
}

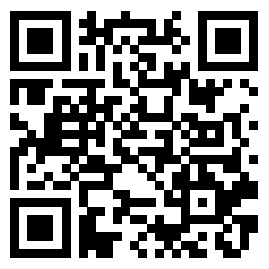

\begin{abstract}
Purpose: This study attempted to examine the active effects of $70 \%$ ethanol extracts of parsley (Petroselinum crispum) and verify its usefulness as an ingredient of functional cosmetics. Methods: Parsley was extracted using $70 \%$ ethanol and, to verify its anti-inflammatory, anti-aging, and skin-brightening effects, its total polyphenol content, and total flavonoid content, and 2,2-diphenyl-1-picrylhydrazyl (DPPH) radical scavenging activity, as well as its ability to synthesize nitric oxide (NO), suppress cyclooxygenase 2 (COX2) and inhibit microphthalmia-associated transcription factor (MITF) and tyrosinase were assessed and phospho-extracellular signal-regulated kinase ( $\mathrm{p}$-ERK), phospho-c-Jun N-terminal kinase ( $\mathrm{p}$-JNK). Results: Total polyphenol and flavonoid contents and DPPH radical scavenging activity of parsley extracts were verified. From results of cytotoxicity test on parsley extracts in RAW 264.7, B16F10, and human dermal fibroblast cells, following experiments were conducted at concentrations which cytotoxicity was not observed. The result showed good MITF inhibition, but poor tyrosinase inhibition. In addition, NO and COX2 were inhibited and phosphorylation of JNK was suppressed. Conclusion: Parsley extracts have remarkable anti-oxidant effects and are valuable as a cosmetics ingredient with anti-inflammatory, skin-brightening, and anti-aging effects.
\end{abstract}

Keywords: Parsley, Anti-oxidant, Melanin, Anti-inflammation, Anti-aging

\section{Introduction}

파슬리(parsley)의 학명은 Petroselinum crispum으로, 쌍떡 잎식물 산형화목 미나리과 두해살이풀로 높이는 20-50 cm이 며 짙은 녹색을 띈다. 원산지는 유럽남동부와 아프리카 북부이 며 따뜻한 곳에서는 3 월 중순에 파종하여 6 월에 정식하고 11 월 부터 이듬해 3 월까지 수확한다. 생육적온이 $15-20^{\circ} \mathrm{C}$ 인 호냉성 작물로서 $5^{\circ} \mathrm{C}$ 이상으로만 온도관리를 하면 연중 수확이 가능하 다(Yang et al., 2007). 파슬리를 식용으로 했을 때 정혈, 뇌신 경촉진작용, 피부미용, 점막기능 강화의 효과가 있을 뿐만 아 니라 신장결석, 방광결석 등 신장장애 질환에 대한 효능 및 약 효에 대하여 보고되고 있다(Jeon et al., 2008). 또한 파슬리는 플라보노이드(flavonoid) 계열의 항산화 성분들을 많이 함유하
고 있어 활성산소를 제거하며, 파슬리의 쿠마린(coumarin) 성 분은 항균효과를 가지고 있다(Fejes et al., 2000). 파슬리의 정유 성분은 내장 안에서 부패를 일으키는 박테리아 번식을 방 지할 뿐만 아니라 식욕을 촉진시키는 역할을 한다(Cha et al., 2006). 파슬리에는 독특한 향기를 내는 휘발성 물질인 아피올 (apiol)이 함유되어 있어 식욕증진 및 발한, 보온, 구치제거, 피 로회복작용을 한다고 알려져 있다(Ojala et al., 2000).

현재까지 파슬리의 생리활성 연구로는 파슬리의 잎과 씨의 휘발성 성분(Kim et al., 1990), 파슬리에 대한 연구는 재배시 기에 따른 파슬리의 modified atmosphere (MA)저장 시 저장 성 비교(Yang et al., 2007)의 파슬리 재배에 관한 연구를 비 롯하여 채소류 추출물의 항산화 효과 및 항돌연변이능(Parry et al., 2006), 항염증 천연추출물이 멜라닌생성에 미치는 영향 
(Dorman et al., 2011), 파슬리추출물의 피부 노화 방지와 자극 완화에 대한 효과(Kim et al., 2004), 채소주스 보충을 통한 여 대생의 지질 패턴 및 항산화능 개선 효과(Gupta \& Seshadri, 1952), apigenin의 항염증 효능과 그 작용기전에 관한 연구 (Uada et al., 2004), 파슬리 가루를 첨가한 설기떡의 품질특 성(Lim \& Park, 2011), 항산화 천연화합물이 neuraminidase 및 superoxide dismutase와 catalase의 활성에 미치는 영향 (Nielsen et al., 1999)과 같이 파슬리에 관련된 다양한 연구들 이 보고되었다. 하지만 현재까지 파슬리 추출물을 이용한 화장 품 소재로서의 항산화, 항염증, 멜라닌에 의한 기능성 화장품 생리활성 효능 연구에 대해서는 미비한 실정이다.

따라서, 본 연구에서는 파슬리 추출물의 항산화 활성을 살펴 보고, B16F10 세포에서의 멜라닌 생성 억제효과와 HDF 세포 에서의 MMP1 발현 억제능을 통한 항노화, RAW 264.7 세포에 서의 항염증 효과를 평가함으로써 파슬리 추출물의 기능성 화 장품 소재로서의 생리활성 효능을 알아보고 기초 자료들을 제 공하고자 한다.

\section{Methods}

\section{1. 실험재료}

1) 시료준비

파슬리는 신영에프에스(Korea)에서 독일산을 구입하여 사 용하였으며, 물로 4-5회 씻어 불순물을 제거한 다음 실온에 서 건조시켰다. 건조한 파슬리 $500 \mathrm{~g}$ 을 분쇄하여 $70 \%$ ethanol (Duksan Pure Chemicals, Korea)을 20배로 가한 후에 $37^{\circ} \mathrm{C}$, $100 \mathrm{rpm}$ 인큐베이터(Jeio Tech, Korea) 안에서 $72 \mathrm{~h}$ 추출하 였다. $72 \mathrm{~h}$ 후 추출액을 분리하기 위하여 여과지(Whatman ${ }^{\circledR}$ Filter Papers No.2; GE Healthcare Life Sciences, UK)를 이 용하여 여과한 후 감압 농축(Eyela, Tokyo Rikakikai, Japan) 을 통해 ethanol을 제거한 뒤 동결 건조하여 최종 추출물을 얻 어 본 실험에 사용하였다. 건조 중량에 대한 추출 고형분의 수율 은 $10.58 \%$ 로 확인되었다.

\section{2) 시약}

본 실험에 사용된 시약은 neutral red (NR) solution, Griess reagent, Folin-Ciocalteau's phenol reagent, aluminum nitrate $\left[\mathrm{Al}\left(\mathrm{NO}_{3}\right)_{3}\right]$, potassium acetate $\left(\mathrm{CH}_{3} \mathrm{COOK}\right)$, caffeic acid, quercetin, formaldehyde, glacial acetic acid, lipopolysaccharide (LPS), DPPH, ascorbic acid, phosphate buffered saline (PBS), $p$-nitrophenyl phosphate, $\mathrm{p}$-ERK, $\mathrm{p}-\mathrm{JNK}$, anti-mouse IgG-Ab를 Sigma-Aldrich (USA)로 부터 구입하여 사용하였으며, sodium carbonate $\left(\mathrm{Na}_{2} \mathrm{CO}_{3}\right)$ 는
Samchun Pure Chemical (Korea)에서, arbutin은 Alfa Aesar (USA)에서 구입하여 사용하였다.

\section{3) 세포주 및 세포배양}

본 실험에 사용한 세포주인 HDF, B16F10 melanoma, RAW 264.7 macrophage 세포는 한국세포주은행(Korean Cell Line Bank, Korea)에서 구입하여 사용하였으며, high glucose Dulbecco's modified Eagle's medium (DMEM; SigmaAldrich) 배지에 $10 \%$ fetal bovine serum (FBS; SigmaAldrich)과 $1 \%$ penicillin/streptomycin (100 IU/mL; GE Healthcare Life Sciences)를 첨가하여 사용하였고, $37^{\circ} \mathrm{C}, 95 \%$ 습도, $5 \% \mathrm{CO}_{2}$ 조건에서 배양하였다.

\section{2. 항산화 실험 측정}

\section{1) $\mathrm{DPPH}$ radical 소거능 측정}

$\mathrm{DPPH}$ radical 소거활성은 Blois (1958) 방법을 이용하여 측 정하였다. 파슬리 추출물을 농도별로 희석한 후 96 well plate에 $10 \mathrm{mM} \mathrm{DPPH}$ 용액 $180 \mu \mathrm{L}$ 와 시료액 $20 \mu \mathrm{L}$ 를 혼합하여 차광 상태에서 $37^{\circ} \mathrm{C}, 30 \mathrm{~min}$ 간 반응시킨 후 Synergy HT (BioTek Instruments, USA)를 이용하여 $517 \mathrm{~nm}$ 에서 흡광도를 측정하 였다. 동일한 조건으로 3 회 반복적으로 실험하여 평균값을 측정 하였으며, 양성 대조군으로는 ascorbic acid를 사용하였다.

$\mathrm{DPPH}$ radical 소거 활성 $(\%)=100-\{($ 첨가군 흡광도/무첨가군 흡광도 $) \times 100\}$

\section{2) 총 폴리페놀 함량 측정}

총 폴리페놀 함량 측정은 Association of Official Agricultural Chemists (AOAC)의 Folin \& Denis (1912)의 방 법을 수정하여 Folin-Ciocalteau's phenol reagent가 시료의 페놀성 화합물에 의해 환원되면, 몰리브덴 청색(molybdenum blue)으로 발색되는 원리를 이용하여 정량하였다(Gutfinger, 1981). 파슬리 추출물을 각 농도별로 희석한 후 시료 $400 \mu \mathrm{L}$ 와 Folin-Ciocalteau's phenol reagent $400 \mu \mathrm{L}$ 를 혼합하여 3 $\min$ 간 실온에서 반응시켰다. 반응시킨 후 $10 \% \mathrm{Na}_{2} \mathrm{CO}_{3}$ 를 400 $\mu \mathrm{L}$ 를 혼합하여 암실에서 $60 \mathrm{~min}$ 반응시킨 후 상등액 $200 \mu \mathrm{L}$ 씩 96 well plate에 분주하여 Synergy HT를 이용하여 $760 \mathrm{~nm}$ 에 서 흡광도를 측정하였다. 동일한 조건으로 3 회 반복적으로 실험 하여 평균값을 측정하였으며, 표준물질 caffeic acid를 사용하였 다.

\section{3) 총 플라보노이드 함량 측정}

총 플라보노이드 함량 측정은 Moreno et al. (2000) 방법을 수정 및 변형하여 측정하였다. 파슬리 추출물을 각각 $0.2,0.5$, $1,2,5 \mathrm{mg} / \mathrm{mL}$ 로 희석한 후 시료 $100 \mu \mathrm{L}$ 와 $10 \% \mathrm{Al}\left(\mathrm{NO}_{3}\right)_{3} 20$ 
$\mu \mathrm{L}, 1 \mathrm{M} \mathrm{CH}_{3} \mathrm{COOK} 20 \mu \mathrm{L}$, ethanol $860 \mu \mathrm{L}$ 를 차례로 혼합하 여 실온에서 $40 \mathrm{~min}$ 간 방치 후 원심분리기(FinePCR, Korea) 로 부유물을 가라앉힌 후 96 well plate에 $200 \mu \mathrm{L}$ 씩 분주하여 Synergy HT를 이용하여 $415 \mathrm{~nm}$ 에서 흡광도를 측정하였다. 동 일한 조건으로 3 회 반복적으로 실험하여 평균값을 측정하였으 며, 표준물질 quercetin을 사용하였다.

\section{3. 세포 생존율}

파슬리 추출물의 세포 생존율에 미치는 영향을 알아보기 위 해 NR assay를 이용하여 분석을 실시하였다(Borenfreund \& Puerner, 1985). HDF, RAW 264.7, B16F10 세포를 96 well plate에 well 당 $3 \times 10^{4}$ cells/well의 세포를 $24 \mathrm{~h}$ 동안 $\mathrm{CO}_{2}$ 인 큐베이터(Jeio Tech)에서 부착시킨 후, 시료를 농도별로 처리한 다음 $37^{\circ} \mathrm{C}$ 에서 $\mathrm{CO}_{2}$ 인큐베이터에서 $48 \mathrm{~h}$ 동안 배양하였다. 48 $\mathrm{h}$ 후 NR solution 용액이 $1 \%$ 포함된 무 혈청배지로 교환 후, 3 $\mathrm{h}$ 동안 배양한 다음 세포 고정액으로 $10 \%$ formaldehyde 용액 이 첨가된 $\mathrm{PBS}$ 를 각 well에 $100 \mu \mathrm{L}$ 로 $20 \mathrm{~min}$ 동안 처리 및 고 정하였다. NR desorb solution (1\% glacial acetic acid, 49\% ethanol, 50\% distilled water)을 각 well에 $100 \mu \mathrm{L}$ 을 가하여 세포 내의 NR을 추출하고 $540 \mathrm{~nm}$ 에서 Synergy HT를 이용하 여 흡광도를 측정하였다. 실험은 3 회 반복 실시 후 $t$-test를 통 해 통계적으로 각각의 유의성을 확인하였다.

$$
\text { 세포생존율 }(\%)=\frac{\text { 시료첨가군의 흡광도 }(540 \mathrm{~nm})}{\text { 시료무첨가군의 흡광도 }(540 \mathrm{~nm})} \times 100
$$

\section{NO 생성 저해능 측정}

파슬리 추출물의 NO 생성 저해능을 알아보기 위해 Green et al. (1982)의 방법에 따라 세포 배양액 내 NO 양을 nitrite $\left(\mathrm{NO}_{2}^{-}\right)$와 nitrate $\left(\mathrm{NO}_{3}^{-}\right)$형태로 측정하였다. $\mathrm{RAW} 264.7$ 세 포를 96 well plate에 well당 $5 \times 10^{4}$ cells/well의 농도로 분주 하고 $24 \mathrm{~h}$ 동안 배양 후, 배지를 제거한 다음 LPS $1 \mu \mathrm{g} / \mathrm{mL}$ 포 함된 배지에 시료를 농도별로 처리 후 $48 \mathrm{~h}$ 배양하였다. 새로 운 plate에 배양된 세포 상층액 $100 \mu \mathrm{L}$ 와 Griess reagent 100 $\mu \mathrm{L}$ 을 가하여 차광된 상태에서 $10 \mathrm{~min}$ 간 반응시키고 Synergy $\mathrm{HT}$ 를 이용하여 $540 \mathrm{~nm}$ 에서 흡광도를 측정하였다.

$\mathrm{NO}$ 생성 저해능 $(\%)=\frac{\text { 시료첨가군의 흡광도 }(540 \mathrm{~nm})}{\text { 시료무첨가군의 흡광도 }(540 \mathrm{~nm})} \times 100$

\section{Western blotting}

파슬리 추출물이 항염증과 관련된 COX2 발현 억제능 측 정, 멜라닌 생성에 필요한 단백질인 MITF와 tyrosinase의 발 현에 미치는 영향 및 MMP1 생성에 중요하게 작용하는 kinase 인 ERK와 JNK의 세포 내 활성화에 미치는 영향을 확인하기 위 해 western blotting을 수행하였다. 파슬리 추출물을 $25,50 \mu$ $\mathrm{g} / \mathrm{mL}$ 농도로 처리 후 RAW 264.7와 B16F10, HDF 세포를 수 확하여 radioimmunoprecipitation assay (RIPA) buffer [Tris$\mathrm{Cl}, 50 \mathrm{mM}$ sodium chloride (NaCl; Sigma-Aldrich), $1 \% \mathrm{NP}-$ 40, $0.5 \%$ sodium deoxycholate, $0.1 \%$ sodium dodecyl sulfate (SDS), protease inhibitor cocktail; Roche, Switzerland]를 첨가하고 세포를 용해하였다. 용해된 RAW 264.7와 B16F10, $\mathrm{HDF}$ 세포는 원심 분리하였고, 상등액은 단백질을 변성시킨 후 sodium dodecyl sulfate-polyacrylamide gel electrophoresis (SDS-PAGE)를 이용하여 분리하였다. 분리된 단백질은 $100 \mathrm{~V}$ 의 조건에서 nitrocellulose membrane (Whatman ${ }^{\circledR}$ )으로 transfer 한 다음 membrane에 옮겨진 단백질은 $5 \%$ skim milk (SigmaAldrich) 용액에서 blocking 처리한 후 $1 \times$ tris-buffered saline with tween 20 [TBST; $150 \mathrm{mM} \mathrm{NaCl}, 10 \mathrm{mM}$ Tris$\mathrm{Cl}(0.2 \%$ Tween $20, \mathrm{pH}$ 7.5)]에 희석한 $\beta$-actin primary antibody (1:10,000; Sigma-Aldrich), anti-COX2 antibody produced in rabbit (1:200; Sigma-Aldrich), anti-MITF antibody produced in rabbit (1:3,000; Sigma-Aldrich), anti-tyrosinase antibody produced in mouse (1:3,000; Sigma-Aldrich)를 처리하고 $24 \mathrm{~h}$ 동안 교반하였다. Secondary antibody는 anti-mouse IgG antibody, anti-rabbit IgG antibody (Santa Cruz Biotechnology, USA)을 사용하여 30 $\min$ 교반하였으며, 교반이 완료된 membrane은 TBST로 세척 하였다. 세척이 완료 된 후 실험용 필름(Konica Minolta, Japan) 에서 SuperSignal ${ }^{\mathrm{TM}}$ West Pico Chemiluminescent Substrate (Thermo Fisher Scientific, USA)을 처리하여 필름에 감광을 유 도한 다음 암실에서 자동현상기(QX-130II; Konica)를 이용하 여 현상하였다. 현상된 필름상의 단백질양은 Image J (National Institutes of Health, USA)를 이용하여 band 농도차이를 비교 하였다.

\section{6. 통계처리}

본 연구의 모든 실험은 동일한 조건하에 독립적으로 3 회 이 상 실시하여 실험 결과를 얻었으며, 모든 실험 결과는 평균 \pm 표 준편차(mean \pm standard deviation, $\mathrm{M} \pm \mathrm{SD}$ )로 표기하였다. 통 계 처리는 Statistical Package for the Social Sciences (SPSS) Window Version 17.0 (IBM, USA)을 이용하여 분석하였으며, 유의성 검증은 Student's $t$-test를 실시하였고, $p$ 값이 0.05 미 만일 때 통계적으로 유의한 차이가 있는 것으로 판정하였다.

\section{Results and Discussion}

\section{1. 항산화 효과 측정 결과}

1) $\mathrm{DPPH}$ radical 소거능 


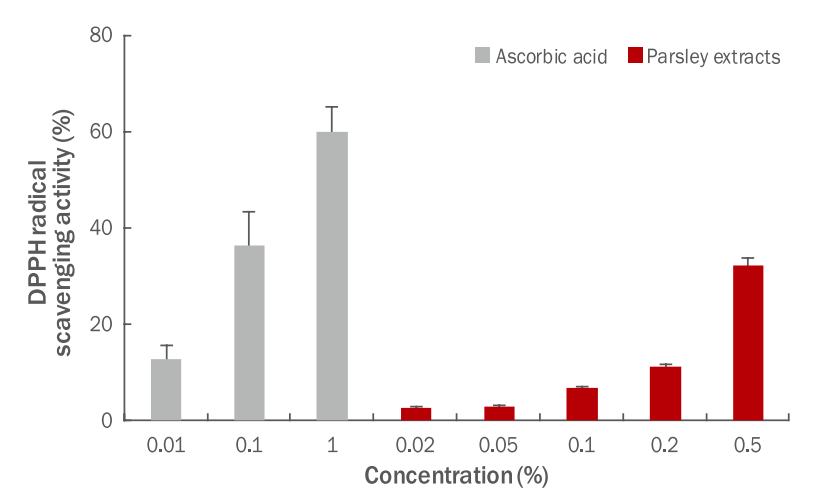

Figure 1. DPPH radical scavenging activity of parsley extracts. Free radical scavenging activity was carried out so as to measure anti-oxidant activity of parsley extracts. Moreover, ascorbic acid was used as comparative material (positive control). The concentration-dependent free radical scavenging activity of the parsley extract was confirmed. Results are expressed as $\mathrm{M} \pm \mathrm{SD}$ of three independent experiments. DPPH, 2,2-diphenyl-1picrylhydrazyl; $\mathrm{M} \pm \mathrm{SD}$, mean \pm standard deviation.

Free radical은 인체의 단백질, 지질 등과 반응하는 노화의 원인 물질로 알려져 있으며, $\mathrm{DPPH}$ 방법에 의한 free radical 소거능은 안정한 활성산소종(reactive oxygen species, ROS) 으로 항산화 물질의 항산화력을 검증하는데 널리 사용되고 있 다. 파슬리 추출물의 항산화 효과를 알아보기 위하여 $\mathrm{DPPH}$ radical 소거 활성을 측정한 결과를 Figure 1에 나타냈으며, 양 성 대조군으로 사용한 ascorbic acid는 $1 \%$ 의 농도에서 $60 \%$ 의 라디칼 소거 활성이 확인되었으며, 파슬리 추출물 $0.5 \%$ 농도에 서는 $32.0 \%$ 의 라디칼 소거 활성을 확인하였다. $\mathrm{DPPH}$ 라디칼 소거능을 측정한 결과 추출물의 농도가 증가함에 따라 $\mathrm{DPPH}$ 소거 활성에는 큰 영향을 미치지 않는 것으로 확인하였다.

\section{2) 총 폴리페놀 함량 변화}

폴리페놀 화합물은 대사 과정 중에 발생하는 유해한 과 산화물질을 제거하여 항산화, 항알러지, 항균, 항암, 충 치예방, 당뇨성질환 예방 및 심장질환 등에 효과가 있으 며 총 폴리페놀 함량이 증가할수록 항산화 생리활성이 증 가하는 경향으로 보고되고 있다(Halliwell et al., 1995; Imai et al., 1994). 총 폴리페놀 함량을 측정하기 위하 여 파슬리 추출물을 $0.2,0.5,1,2,5 \mathrm{mg} / \mathrm{mL}$ 의 농도로 실 험에 사용하였다. Caffeic acid를 표준 용액으로 하여 파 슬리 추출물의 총 폴리페놀 함량을 환산하였다. 실험 결 과는 Figure 2에 나타냈으며, 파슬리 추출물의 총 폴리페 놀 함량은 $12.25 \mathrm{mg}$ caffeic acid equivalent (CAE)/100 g 이었으며 농도 의존적으로 증가하는 양상을 나타내었다.

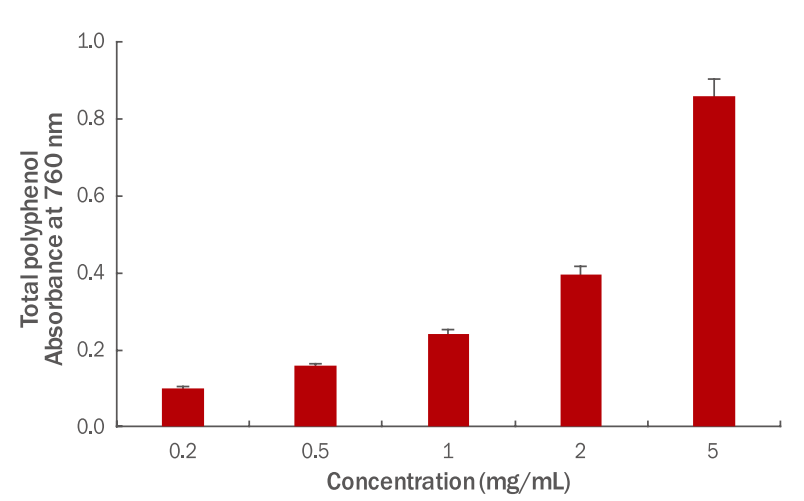

Figure 2. Total polyphenol content of parsley extracts. Total polyphenol content in parsley extracts was measured. In the result, the content of total polyphenol in the parsley extracts was $12.25 \mathrm{mg} \mathrm{CAE} / 100 \mathrm{~g}$ and increased in a concentration-dependent manner. Results are expressed as $\mathrm{M} \pm \mathrm{SD}$ of three independent experiments. $C A E$, caffeic acid equivalent; $M \pm S D$, mean \pm standard deviation.

\section{3) 총 플라보노이드 함량 변화}

플라보노이드는 폴리페놀에 속하는 성분으로, $\mathrm{C} 6-\mathrm{C} 3-\mathrm{C} 6$ 을 기본골격으로 하여 노란색 또는 담황색을 나타내는 페놀계 화합물을 총칭한다(Hertog et al., 1993). 또한, 플라보노이 드는 식물계에 분포하는 이차 대사물로 구조적으로 phenolic hydroxyl기가 존재하여 free radical 소거 활성이 우수하고, 자외선에 대한 필터작용, 활성산소 제거를 통한 항산화 작용 을 하는 것으로 알려져 있다(Havsteen, 1983). 파슬리 추출 물의 총 플라보노이드 함량을 측정하기 위하여 파슬리 추출 물을 $0.2,0.5,1,2,5 \mathrm{mg} / \mathrm{mL}$ 의 농도로 실험에 사용하였고, quercetin을 표준 용액으로 하여 파슬리 추출물의 총 플라보 노이드 함량을 환산하였다. 본 실험 결과를 Figure 3에 나타냈 으며, 파슬리 추출물의 총 플라보노이드의 함량은 $80.99 \mathrm{mg}$ quercetin $(\mathrm{QE}) / 100 \mathrm{~g}$ 이었으며 농도 의존적으로 증가하는 양 상을 나타내었다.

\section{2. 세포 생존율 측정 결과}

1) RAW 264.7 세포에 대한 세포 생존율

마우스 대식세포인 RAW 264.7 세포에서 세포 생존율에 미치 는 영향을 알아보기 위하여 $70 \%$ 에탄올을 이용한 파슬리 추출 물을 $5,10,20,50,100 \mu \mathrm{g} / \mathrm{mL}$ 의 농도로 처리하고, $48 \mathrm{~h}$ 배양 하여 NR assay를 실시하였다. 본 실험 결과, 파슬리 추출물 5 , $10,20,50 \mu \mathrm{g} / \mathrm{mL}$ 농도까지 $90 \%$ 이상의 세포 생존율을 나타났 으며, $100 \mu \mathrm{g} / \mathrm{mL}$ 에서 세포 생존율이 $14.3 \%$ 감소함을 확인하 였다. 본 실험을 통해 파슬리 추출물이 $50 \mu \mathrm{g} / \mathrm{mL}$ 농도까지는 RAW 264.7 세포에 대한 독성이 나타나지 않는 것을 확인하여 


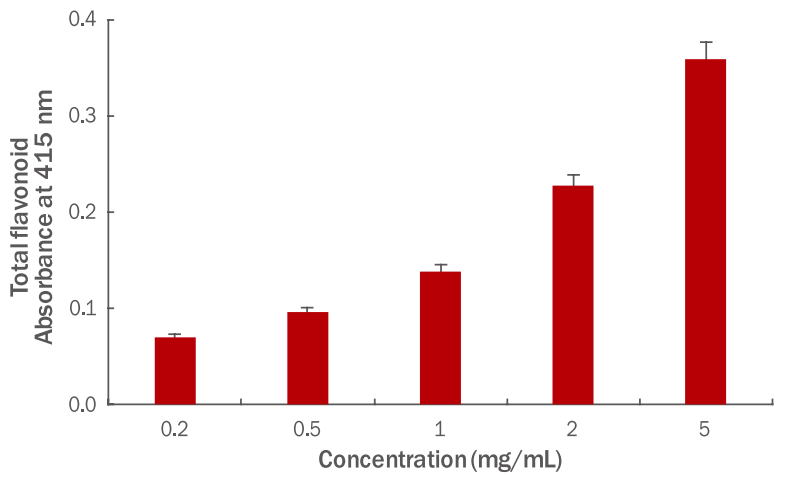

Figure 3. Total flavonoid content of parsley extracts.

Total flavonoid content in parsley extracts was measured. In the result, the content of total flavonoid in the parsley extracts was $80.99 \mathrm{mg}$ QE/100 g and increased in a concentration-dependent manner. Results are expressed as $\mathrm{M} \pm \mathrm{SD}$ of three independent experiments. $\mathrm{QE}$, quercetin equivalent; $\mathrm{M} \pm \mathrm{SD}$, mean \pm standard deviation.

추후 실험은 $50 \mu \mathrm{g} / \mathrm{mL}$ 농도에서 진행하였다(Figure $4 \mathrm{~A}$ ).

2) $\mathrm{B} 16 \mathrm{~F} 10$ 세포에 대한 세포 생존율

$\mathrm{B} 16 \mathrm{~F} 10$ 세포에서 세포 생존율에 미치는 영향을 알아보기 위 하여 $70 \%$ 에탄올을 이용한 파슬리 추출물을 $5,10,20,50$, $100 \mu \mathrm{g} / \mathrm{mL}$ 의 농도로 처리하고, $48 \mathrm{~h}$ 배양하여 NR assay 를 실시하였다. 본 실험 결과, 파슬리 추출물 $5,10,20,50$, $100 \mu \mathrm{g} / \mathrm{mL}$ 농도까지 $95 \%$ 이상의 세포 생존율을 나타났으며, 모든 농도에서 세포 독성이 나타나지 않는 것을 확인하였다 (Figure 4B).

\section{3) $\mathrm{HDF}$ 세포에 대한 세포 생존율}

인간 섬유 세포인 $\mathrm{HDF}$ 세포에서의 세포 생존율에 미치는 영향을 알아보기 위하여 $70 \%$ 에탄올을 이용한 파슬리 추출물 을 $5,10,20,50,100 \mu \mathrm{g} / \mathrm{mL}$ 의 농도로 처리하고, $48 \mathrm{~h}$ 배양 하여 NR assay를 실시하였다. 본 실험 결과, 파슬리 추출물 5 , $10,20,50 \mu \mathrm{g} / \mathrm{mL}$ 농도까지 $95 \%$ 이상의 세포 생존율을 나타 났으며, $100 \mu \mathrm{g} / \mathrm{mL}$ 에서 세포 생존율이 $8.3 \%$ 감소함을 확인 하였다. 본 실험을 통해 파슬리 추출물은 $\mathrm{HDF}$ 세포에 대한 독 성이 나타나지 않는 것을 확인하였고, 추후 실험은 파슬리 추 출물의 세포 생존율이 $95 \%$ 이상인 $50 \mu \mathrm{g} / \mathrm{mL}$ 농도에서 진행 하였다(Figure 4C).

\section{3. 항염증 효과 측정 결과}

\section{1) $\mathrm{NO}$ 생성 저해능 측정}

활성 질소종(reactive nitrogen species, RNS)의 하나이며, 최근 염증 반응의 중요한 작용인자로 알려진 $\mathrm{NO}$ 의 생성 저해에 미치는


Figure 4. The cytotoxicity of parsley extract was measured. (A) The cytotoxicity of parsley extracts was measured in RAW 264.7 macrophage cells. In the result, cell viability was $90 \%$ or higher up to $5,10,20,50 \mu \mathrm{g} / \mathrm{mL}$ and decreased by $14.3 \%$ at $100 \mu \mathrm{g} / \mathrm{mL}$. (B) The cytotoxicity of parsley extracts was measured in B16F10 melanoma cells. It was verified that cytotoxicity was not shown in all indicated concentrations. (C) The cytotoxicity of parsley extracts was measured in HDF cells. In the result, cell viability was $95 \%$ or higher up to $5,10,20,50 \mu \mathrm{g} / \mathrm{mL}$ concentrations, and decreased by $8.3 \%$ at $100 \mu \mathrm{g} / \mathrm{mL}$. The extracts were compared with the untreated group. Results are expressed as $\mathrm{M} \pm \mathrm{SD}$ of three independent experiments. $\mathrm{M} \pm \mathrm{SD}$, mean \pm standard deviation. 




Figure 5. Inhibitory effects of parsley extracts on antiinflammation in RAW 264.7 macrophage cells.

RAW 264.7 macrophage cells were treated with LPS $(1 \mu \mathrm{g} / \mathrm{mL})$. The inhibitory effects of parsley extracts on anti-inflammation were measured. The results were compared between only treated with LPS group and experimental group which both treated with LPS and parsley extracts, and an inhibitory effects on NO production were checked at $10,20,50 \mu \mathrm{g} / \mathrm{mL}$ concentrations of parsley extracts. The results are presented as the $\mathrm{M} \pm \mathrm{SD}$ of three independent experiments and statistical significance was shown ( $\left.{ }^{*} p<0.05\right)$. NO, nitric oxide; LPS, Lipopolysaccharide; $\mathrm{M} \pm \mathrm{SD}$, mean \pm standard deviation.

파슬리 추출물의 효과를 알아보기 위하여, 대식세포인 RAW 264.7 세포에 NO 생성을 유도하는 LPS가 처리된 배지와 파슬리 추출물 을 $5,10,20,50 \mu \mathrm{g} / \mathrm{mL}$ 농도별로 처리하여 $\mathrm{NO}$ 생성 억제능을 측 정하였다(Figure 5). 본 실험 결과, LPS 단독 처리군에 비해 파슬 리 추출물은 $20 \mu \mathrm{g} / \mathrm{mL}$ 에서 $12 \%$ 감소하였고 $\left.{ }^{*} p<0.05\right), 50 \mu \mathrm{g} / \mathrm{mL}$ 에서 $46.8 \%$ 의 $\mathrm{NO}$ 생성 억제율을 나타내었다 $\left.{ }^{*} p<0.05\right)$. 이와 같 은 결과를 통해 파슬리 추출물은 LPS에 의해 유도된 NO 생성을 억 제함으로써 항염증 효과가 있음을 확인하였다. 따라서 RAW 264.7 세포에서의 항염증의 생성억제가 확인됨에 따라 염증인자를 억제 하는 세포활성에 기여할 수 있을 것으로 사료된다.

\section{2) COX2 발현 억제능 측정}

본 실험에서는 염증 매개 물질인 LPS를 대식세포인 RAW 264.7 세포에 처리한 후 $70 \%$ 에탄올로 추출한 파슬리 추출물을 25,50 $\mu \mathrm{g} / \mathrm{mL}$ 로 처리하고 western blotting을 이용하여 RAW 264.7 세 포 내 COX2 단백질 발현 억제 효과를 확인하였다(Figure 6). 정 확한 발현량을 확인하고자 COX2 High와 Low로 발현 노출 시간 의 차이를 두고 동일한 방법으로 측정하였다(Figure 8A). 두 처리 군 모두 LPS에 의해 COX2 발현량이 유의하게 증가되었고, High 는 $50 \mu \mathrm{g} / \mathrm{mL}$ 농도에서 유의한 저해 효과가 확인 되었으며, Low 는 파슬리 추출물 $25,50 \mu \mathrm{g} / \mathrm{mL}$ 의 농도에서 유의하게 저해되었 다(Figure $8 \mathrm{~B} ;{ }^{* *} p<0.01,{ }^{* * *} p<0.001$ ). NO에 의해 생성된 COX2 는 염증과정에서 인지질을 대사시켜 생성된 arachidonic acid에
A
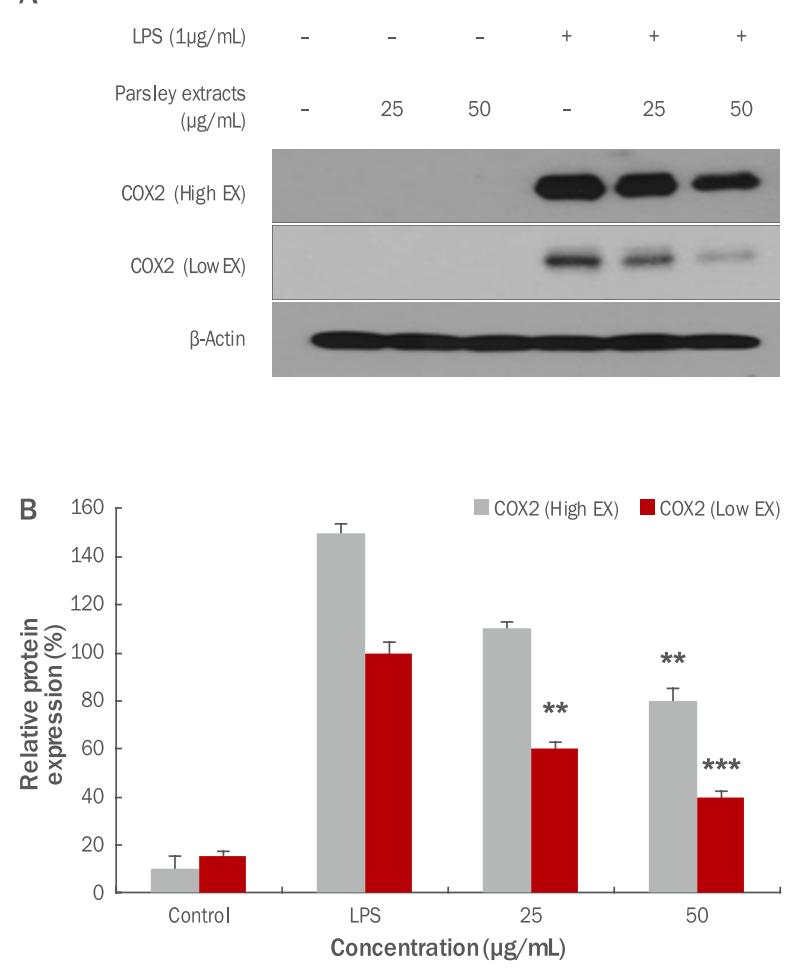

Figure 6. Inhibitory effects of parsley extracts on COX2 activation in RAW 264.7 macrophage cells.

In order to check the anti-inflammatory effects of parsley extracts, RAW 264.7 macrophage cells were treated with LPS and inhibitory effects on COX2 activity were measured by using western blotting. To determine the exact expression level, COX2 high and low were measured by the same method with different exposure time. The results, were compared between only treated with LPS group and experimental group which both treated with LPS and parsley extracts and it was determined that COX2 activity was significantly inhibited by parsley extracts. (A) A variation of COX2 protein expression due to parsley extracts was shown. (B) COX2 protein expression due to parsley extracts is graphed. The results are presented as the $M \pm S D$ of three independent experiments $\left({ }^{* *} p<0.01 ;{ }^{* * *} p<0.001\right)$. LPS, lipopolysaccharide; Control, untreated group; COX2, cyclooxygenase 2; EX, exposure; $\mathrm{M} \pm \mathrm{SD}$, mean \pm standard deviation.

서 prostaglandin $\mathrm{E}_{2}\left(\mathrm{PGE}_{2}\right)$ 를 생성시키는 효소이고, $\mathrm{COX} 2$ 에 의 해 생성된 $\mathrm{PGE}_{2}$ 는 혈관확장, 통증 및 발열 작용을 하는 것으로 알 려져 있으며, 과도한 COX2의 발현은 암 조직에 있어서 혈관신생 (angiogenesis) 및 전이능(metastatic potential)을 높이고 세포사 멸을 억제하는 것으로 알려져 있으며 COX2의 염증반응은 세포 의 암화(carcinogenesis)에도 관련이 되어 있음이 보고되고 있다 (Baldwin, 1996). 이러한 결과를 통하여 파슬리 추출물은 RAW 264.7 대식세포에서 COX2를 효과적으로 억제하는 기능으로 보아 피부 염증 반응을 효과적으로 억제하는데 관여할 수 있을 것으로 사료된다. 
A
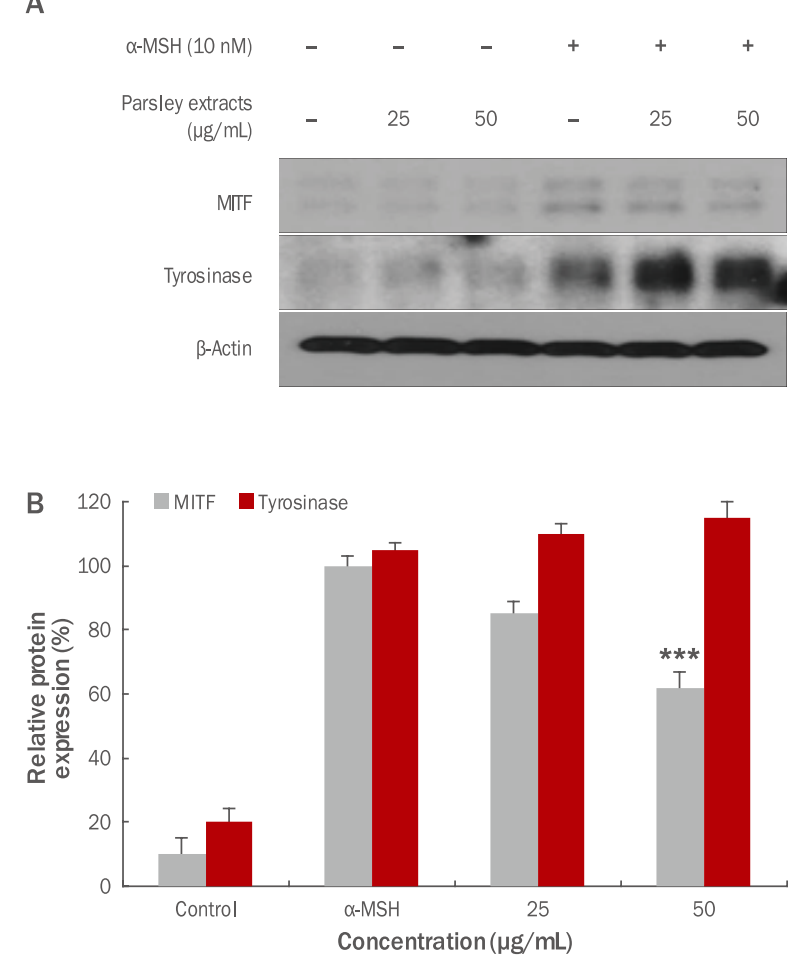

Figure 7. Inhibitory effects of parsley extracts on MITF and tyrosinase activation in B16F10 melanoma cells.

In order to check the whitening effects of parsley extracts, B16F10 melanoma cells were treated with $\alpha-\mathrm{MSH}$. Then, inhibitory effects on MITF, tyrosinase activity were measured by using western blotting. The results were compared between $\alpha$-MSH group and experimental group which both treated with $\alpha-\mathrm{MSH}$ and parsley extracts and in MITF expression, significant inhibitory effects were checked. (A) A variation of MITF, tyrosinase protein expression due to parsley extracts was shown. (B) MITF, tyrosinase protein expression due to parsley extracts was graphed. The results are presented as the $\mathrm{M} \pm \mathrm{SD}$ of three independent experiments $\left({ }^{* * *} p<0.001\right) . \alpha-\mathrm{MSH}, \alpha$-melanocyte-stimulating hormone; MITF, microphthalmia-associated transcription factor; $\mathrm{M} \pm \mathrm{SD}$, mean \pm standard deviation.

\section{4. 항멜라닌 효과 측정 결과}

파슬리 추출물의 항멜라닌 효과를 측정하기 위하여 MITF, tyrosinase의 발현량 변화를 확인하였다. 멜라닌 생합성 자극 호르몬인 $\alpha$-melanocyte-stimulating hormone ( $\alpha-\mathrm{MSH})$ $10 \mathrm{nM}$ 을 멜라닌 형성세포인 $\mathrm{B} 16 \mathrm{~F} 10$ 세포에 처리하였다. $\alpha$ $-\mathrm{MSH}$ 를 처리 후 멜라닌 발현을 활성화시키고, 파슬리 추출물 을 $25,50 \mu \mathrm{g} / \mathrm{mL}$ 의 농도별로 처리한 후 western blotting을 이용하여 MITF, tyrosinase의 활성억제 효과를 확인하였다 (Figure 7). 본 실험 결과, 파슬리 추출물에 의해 MITF의 활성 이 $25 \mu \mathrm{g} / \mathrm{mL}$ 농도에서 $15.0 \%, 50 \mu \mathrm{g} / \mathrm{mL}$ 농도에서 $38.2 \%$ 의 농도별로 우수한 억제 효과를 보였으며, 그에 반해 tyrosinase
A
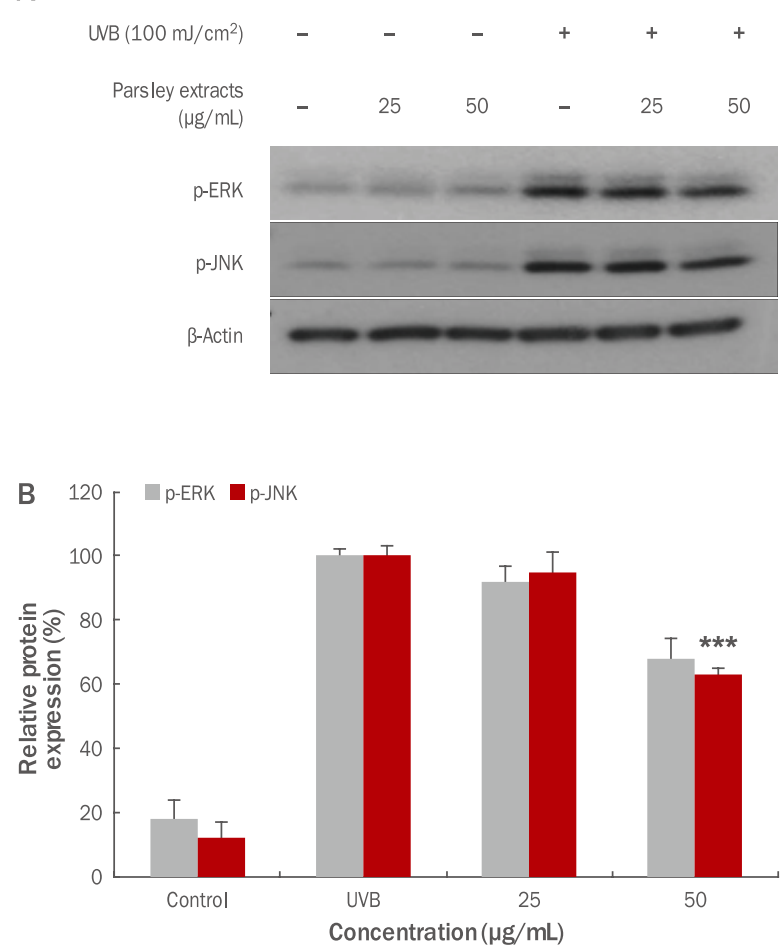

Figure 8. Inhibitory effects of parsley extracts on the activation of $p$-ERK and p-JNK by UVB in HDF cells.

In order to check the anti-aging effects of parsley extracts, HDF cells were treated with UVB, and inhibitory effects on p-ERK and p-JNK activity were measured by using western blotting. From results $p$-JNK significant inhibitory effects were checked. (A) A variation of $p-E R K$ and $p-J N K$ protein expression due to parsley extracts was shown. (B) p-ERK and p-JNK protein expression due parsley extracts was graphed. The results are presented as the $M \pm S D$ of three independent experiments. Statistical significance was shown $\left({ }^{* * *} p<0.001\right)$. UVB, ultraviolet B; $p$-ERK, phospho-extracellular signal-regulated kinase; $p$-JNK, phosphoc-Jun N-terminal kinase; HDF, human dermal fibroblast; $\mathrm{M} \pm \mathrm{SD}$, mean \pm standard deviation.

억제 효과는 나타나지 않는 것으로 확인되었다. 이와 같은 결 과를 통하여 tyrosinase의 억제 효과가 나타나지 않아 미백 효 과는 미약하나, MITF에 의한 미백 효과는 우수한 것으로 확인 되었다.

\section{5. 항노화 효과 측정 결과}

$\mathrm{HDF}$ 세포에 ultraviolet B (UVB)가 조사되면 세포 내 DNA 손상뿐만 아니라 광노화 현상이 발생하며, $\mathrm{HDF}$ 세포의 광노화 는 성장을 저해하며 MMP1의 발현을 촉진하여 진피층에 존재 하는 콜라겐의 분해를 촉진시키는 것으로 알려져 있다(Yoon, 2013). 본 연구에서는 UVB에 의한 $M M P 1$ 유전자 발현에 관련 있다고 알려진 $\mathrm{p}-\mathrm{ERK}$ 와 $\mathrm{p}-\mathrm{JNK}$ 의 인산화 정도를 western 
blotting을 이용하여 측정하였다. 파슬리 추출물을 $25,50 \mu$ $\mathrm{g} / \mathrm{mL}$ 농도로 각각 처리한 후 UVB lamp (Johnsam, Korea) 를 이용하여 $100 \mathrm{~mJ} / \mathrm{cm}^{2}$ 의 강도로 조사하였다. 본 실험 결과, Figure 8에서 볼 수 있듯이 UVB 조사 후 $\mathrm{p}-\mathrm{ERK}$ 와 $\mathrm{p}-\mathrm{JNK}$ 의 단백질 발현이 파슬리 추출물 처리에 의해 감소된 것을 확 인할 수 있었고(Figure $8 \mathrm{~A}$ ), p-JNK의 $50 \mu \mathrm{g} / \mathrm{mL}$ 농도에서 $37.0 \%$ 유의하게 저해되었다(Figure $8 \mathrm{~B} ;{ }^{* * *} p<0.001$ ). 이와 같은 결과는 파슬리 추출물이 $\mathrm{HDF}$ 세포에서 UVB에 의해 유 도된 JNK의 인산화를 억제 함으로써 콜라겐 분해를 촉진하는 $M M P 1$ 유전자의 발현을 억제하여 주름 개선에 도움을 주는 것 으로 사료된다.

\section{$\overline{\text { Conclusion }}$}

본 연구에서는 파슬리 추출물의 항산화 및 항염증, 항멜라 닌, 항노화의 기능성 화장품 소재로서의 생리활성 효능을 알 아보고자 하였다. 항산화 활성 효과를 측정하기 위하여 $\mathrm{DPPH}$ radical 소거능, 총 폴리페놀 함량, 총 플라보노이드 함량을 확 인하였다. DPPH radical 소거능을 확인한 결과 농도 의존적 인 DPPH radical 소거 활성이 확인 되었으며, 총 폴리페놀 함 량은 $12.25 \mathrm{mg} \mathrm{CAE} / 100 \mathrm{~g}$ 이었으며, 총 플라보노이드 함량 측정 결과 $80.99 \mathrm{mg} \mathrm{QE} / 100 \mathrm{~g}$ 으로 총 폴리페놀와 총 플라 보노이드 모두 농도 의존적으로 증가하는 양상을 나타내었다. 세포 생존율 측정을 위해 파슬리 추출물을 농도에 따라 RAW 264.7, B16F10, HDF 세포에 처리한 결과, 세포 독성이 나타 나지 않는 농도에서 실험을 수행하였다. 항염증 효과를 측정한 결과, $50 \mu \mathrm{g} / \mathrm{mL}$ 에서 $46.8 \%$ 의 $\mathrm{NO}$ 생성 억제율이 나타났으며, $50 \mu \mathrm{g} / \mathrm{mL}$ 에서도 COX2 단백질 발현 억제효과가 있음을 확인 하였다. 멜라닌 효과 측정 MITF, tyrosinase 발현량 측정결 과, $\mathrm{MITF}$ 의 $25,50 \mu \mathrm{g} / \mathrm{mL}$ 의 농도별로 발현 억제 효과를 보 였으며, 그에 반해 tyrosinase 억제 효과는 나타나지 않는 것 으로 확인하였다. $\mathrm{HDF}$ 세포에서 UVB에 의해 과발현을 유도 하였고, $M M P 1$ 유전자 발현에 관련 있다고 알려진 $\mathrm{p}-\mathrm{ERK}$ 와 $\mathrm{p}-\mathrm{JNK}$ 의 발현 정도를 측정한 결과, 유의한 JNK 인산화 활성 억제 효과를 확인하였다. 따라서 파슬리 추출물의 항산화, 항 염증 및 미백 개선, 주름 개선 효과를 가진 기능성 화장품 소재 로서의 가능성이 있을 것으로 사료된다.

This work is part of the Jung-Eun Choi's Ph.D. thesis at the Konkuk University, Seoul, Korea.

\section{References}

Baldwin AS Jr. The NF-kB and IkB proteins: new discoveries and insights. Annual Review of Immunology, 14: 649-683, 1996.

Blois MS. Antioxidant determinations by the use of a stable free radical. Nature, 181: 1199-1200, 1958.

Borenfreund $\mathrm{E}$, Puerner JA. Toxicity determined in vitro by morphological alterations and neutral red absorption. Toxicology Letters, 24: 119-124, 1985.

Cha WS, Kim JH, Lee KH, Kwon HJ, Yoon SJ, Chun SS, Choi UK, Cho YJ. Antioxidative and inhibition activities on Helicobacter pylori of spice extracts. Journal of the Korean Society of Food Science and Nutrition, 35: 315-320, 2006.

Dorman HJ, Lantto TA, Raasmaja A, Hiltunen R. Antioxidant, prooxidant and cytotoxic properties of parsley. Food \& Function, 2 : 328-337, 2011.

Fejes S, Blázovics A, Lemberkovics É, Petri G, Szöke É, Kéry Á. Free radical scavenging and membrane protective effects of methanol extracts from Anthriscus cerefolium L. (Hoffm.) and Petroselinum crispum (Mill.) Nym. ex A.W. Hill. Phytotherapy Research, 14: 362-365, 2000.

Folin O, Denis W. On phosphotungstic-phosphomolybdic compounds as color reagents. The Journal of Biological Chemistry, 12: 239-243, 1912.

Green LC, Wagner DA, Glogowski J, Skipper PL, Wishnok JS, Tannenbaum SR. Analysis of nitrate, nitrite, and $\left[{ }^{15} \mathrm{~N}\right]$ nitrate in biological fluids. Analytical Biochemistry, 126: 131-138, 1982.

Gupta SR, Seshadri TR. A study of apiin from the parsley seeds and plant. Proceedings of the Indian Academy of Sciences (Mathematical Sciences), 35: 242-248, 1952.

Gutfinger T. Polyphenols in olive oils. Journal of the American Oil Chemists Society, 58: 966-968, 1981.

Halliwell B, Aeschbach R, Löliger J, Aruoma OI. The characterization of antioxidants. Food and Chemical Toxicology, 33: 601-617, 1995.

Havsteen B. Flavonoids, a class of natural products of high pharmacological potency. Biochemical Pharmacology, 32: 1141-1148, 1983.

Hertog MGL, Hollman PCH, van de Putte B. Content of potentially anticarcinogenic flavonoids of tea infusions, wines, and fruit juices. Journal of Agricultural and Food Chemistry, 41: 12421246, 1993.

Imai J, Ide N, Nagae S, Moriguchi T, Matsuura H, Itakura Y. 
Antioxidant and radical scavenging effects of aged garlic extract and its constituents. Planta Medica, 60: 417-420, 1994.

Jeon HY, Kim JK, Kim WG, Lee SJ. Beneficial effect of curcumin on epidermal permeability barrier function in hairless rat. Korean Journal of Food Science and Technology, 40: 686-690, 2008.

Kim SN, Lee SH, Choi GH, Jang IS, Lee BG. Effects of parsley extract on skin anti-aging and anti-irritation. Journal of the Society of Cosmetic Scientists of Korea, 30: 79-83, 2004.

Kim YH, Kim KS, Hong CK. Volatile components of parsley leaf and seed (Petroselinum crispum). Applied Biological Chemistry, 33: 62-67, 1990.

Lim JH, Park JH. The quality characteristics of sulgidduk prepared with parsley powder. Korean Journal of Food and Cookery Science, 27: 101-111, 2011.

Moreno MI, Isla MI, Sampietro AR, Vattuone MA. Comparison of the free radical-scavenging activity of propolis from several regions of Argentina. Journal of Ethnopharmacology, 71: 109$114,2000$.

Nielsen SE, Young JF, Daneshvar B, Lauridsen ST, Knuthsen P Sandström B, Dragsted LO. Effect of parsley (Petroselinum crispum) intake on urinary apigenin excretion, blood antioxidant enzymes and biomarkers for oxidative stress in human subjects. British Journal of Nutrition, 81: 447-455,
1999.

Ojala T, Remes S, Haansuu P, Vuorela H, Hiltunen R, Haahtela K, Vuorela P. Antimicrobial activity of some coumarin containing herbal plants growing in Finland. Journal of Ethnopharmacology, 73: 299-305, 2000.

Parry J, Hao Z, Luther M, Su L, Zhou K, Yu L. Characterization of cold-pressed onion, parsley, cardamom, mullein, roasted pumpkin, and milk thistle seed oils. Journal of the American Oil Chemists' Society, 83: 847-854, 2006.

Ueda $\mathrm{H}$, Yamazaki C, Yamazaki M. A hydroxyl group of flavonoids affects oral anti-inflammatory activity and inhibition of systemic tumor necrosis factor-alpha production. Bioscience, Biotechnology, and Biochemistry, 68: 119-125, 2004.

Yang EM, Park KW, Kang HM. Comparison of storability of fresh parsley grown in different seasons in MA storage. Protected Horticulture and Plant Factory, 16: 67-71, 2007.

Yoon Y. Gene expression profiling in protection mechanism of silibinin against damage to human dermal fibroblasts caused by UVB. Asian Journal of Beauty and Cosmetology, 11: 93-102, 2013

Yoon Y. Gene expression profiling in protection mechanism of silibinin against damage to human dermal fibroblasts caused by UVB. Asian Journal of Beauty and Cosmetology, 11: 93102,2013 


\section{국문초록}

\section{파슬리 추출물의 기능성 화장품 소재로서의 생리활성}

최정은 ${ }^{1}$, 문지선 ${ }^{2 *}$

${ }^{1}$ 건국대학교 생물공학과, 서울, 한국

${ }^{2}$ 중원대학교 뷰티헬스학과, 충청북도 괴산군, 한국

목적: 파슬리(Petroselinum crispum) $70 \%$ 에탄올 추출물의 활성 효능을 확인하여 기능성 화장품 소재로서의 응용 가능성을 검 증하고자 하였다. 방법: 파슬리를 $70 \%$ 에탄올로 추출하여, 항염증 및 항노화, 미백 효과를 확인하기 위하여 총 폴리페놀 함량, 총 플라보노이드 함량, 2,2-diphenyl-1-picrylhydrazyl (DPPH) radical 소거능, nitric oxide (NO) 생성, cyclooxygenase 2 (COX2), microphthalmia-associated transcription factor (MTTF), tyrosinase, phospho-extracellular signal - regulated kinase (p-ERK), phospho-c-Jun N-terminal kinase (p-JNK) 발현량 억제 효과를 측정하였다. 결과: 파슬리 추출물의 플라보노이드, 폴리페놀 함 량과 DPPH radical 소거능을 확인하였으며, RAW 264.7, B16F10, human dermal fibroblast (HDF) 세포에서 파슬리 추출물에 대 한 세포 독성 실험을 진행한 결과, 세포독성이 나타나지 않는 범위에서 실험을 진행하였다. NO 생성 억제 및 COX2 억제효과를 확 인하였고, MTTF 발현량이 억제된 반면 tyrosinase 억제 효과는 나타나지 않는 것으로 확인되었다. 또한 JNK의 인산화가 억제되는 것을 확인하였다. 결론: 파슬리 추출물은 항산화 효과가 우수하고, 항염증 효과와 미백 및 주름 개선 효과를 가지는 다양한 기능성 화장품 소재로서의 가치가 있는 것으로 사료된다.

핵심어: 파슬리, 항산화, 멜라닌, 항염증, 항노화

\section{참고문헌}

김수남, 이소희, 최규호, 장이섭, 이병곤. 파슬리추출물의 피부 노화 방지와 자극 완화에 대한 효과. 대한화장품학회지, 30 : 79-83, 2004.

양은미, 박원우, 강호민. 재배시기에 따른 파슬리의 MA저장시 저장성 비교. 시설원예 · 식물공장, 16: 67-71, 2007.

윤영민. UVB에 대한 Silibinin의 세포보호 기전에 작용하는 유전자 발현 프로파일링. 아시안뷰티화장품학술지, 11: 93-102, 2013.

임점희, 박종희. 파슬리가루를 첨가한 설기떡의 품질특성. 한국식품조리과학회지, 27: 101-111, 2011.

전희영, 김정기, 김완기, 이상준. 무모쥐에서 자외선에 의한 피부 장벽 손상에 미치는 커큐민의 보호 효과. 한국식품과학회지, 40: 686-690, 2008.

차원섭, 김정환, 이경환, 권효정, 윤소정, 천성숙, 최융규, 조영제. 향신료 추출물의 항산화활성 및 Helicobacter pylori 저해효 과. 한국식품영양과학회지, 35: 315-320, 2006. 


\section{中文摘要}

\section{绉叶石蛇床提取物作为功能性化妆品原料的生理活性研究}

崔貞銀 ${ }^{1}$, 文知善 $^{2^{*}}$

建国大学生物工学科, 首尔, 韩国

${ }^{2}$ 中源大学美容健身学科, 忠清北道槐山郡, 韩国

目的: 探讨绉叶石蛇床 $70 \%$ 乙醇提取物的活性功效，评价作为功能性化妆品原料的应用可行性。方法: 利用 $70 \%$ 乙醇提 取绉叶石蛇床提取物, 为确认绉叶石蛇床提取物的抗炎、抗衰老以及美白作用, 测量多酚含量和总黄酮含量, 并测定 2,2-diphenyl-1-picrylhydrazyl（DPPH）自由基消除能力和一氧化氮（nitric oxide，NO）抑制作用, cyclooxygenase 2 (COX2) 、 microphthalmia-associated transcription factor (MITF) 、 tyrosinase, phospho-extracellular signalregulated kinase（ $p$-ERK）以及phospho-c-Jun N-terminal kinase（ $p$-JNK）表达的抑制作用。结果：测量绉叶石蛇床的 多酚含量和总黄酮含量并确定DPPH自由基消除能力。在RAW 264.7, B16F10, human dermal fibroblast（HDF）细胞中, 对谄叶石蛇床进行细胞毒性实验, 并在不出现毒性范围内进行实验。确认NO生成抑制和COX2抑制作用, 同时抑制MITF 表达, 但不出现tyrosinase抑制效果。此外，谄叶石蛇床提取物具有抑制JNK的磷酸化的作用。结论: 谄叶石蛇床提取物 具有优秀的抗氧化、抗炎、美白以及皱纹改善作用，因此作为多种功效的功能性化妆品原料充分具有可行性。

关键词: 绉叶石蛇床, 抗氧化, 黑色素, 抗炎, 抗衰老 